\title{
PENCAK DOR DALAM INDUSTRI OLAHRAGA
}

\author{
Wasis Himawanto \\ Penjaskesrek Universitas Nusantara PGRI Kediri \\ E-mail: himasis_23@unpkediri.ac.id
}

Diterima: 19 November 2017; Lolos: 23 November 2017; Dipublikasikan: 23 November 2017

\begin{abstract}
Abstrak
Indonesia merupakan negara yang memiliki ribuan budaya yang tersebar di seluruh pelosok negerinya. Macam-macam budaya yang ada di Indonesia membuat keberagaman suku dan adat istiadat. Corak dan keberagaman dari budaya Indonesia salah satunya tercermin dari olahraga tradisional yang lahir dalam masyarakat. Tiap budaya memiliki jenis olahraga tradisional yang beragam dan memiliki potensi untuk dikembangkan lebih jauh. Salah satu potensi yang dimiliki adalah pengambangan dalam sektor industri olahraga. Pencak Dor adalah salah satu olahraga tradisional yang memiliki kemampuan untuk menarik partisipan hingga ribuan orang. Dengan manajemen kegiatan yang baik, bukan tidak mungkin Pencak Dor menjadi sebuah olahraga yang dipertandingkan dalam tingkat nasional.
\end{abstract}

Kata kunci: Budaya, olahraga tradisional, bela diri.

\section{PENCAK DOR IN SPORT INDUSTRI}

\begin{abstract}
Indonesia is a country that has thousands of cultures spread all over the country. Various kinds of cultures in Indonesia make the diversity of tribes and customs. The style and diversity of Indonesian culture is reflected in the traditional sports born in society. Each culture has a diverse range of traditional sports and has the potential to be further developed. One of its potentials is mining in the sports industry sector. Pencak Dor is one of the traditional sports that has the ability to attract participants to thousands of people. With good management of activities, it is not impossible Pencak Dor to be a sport that competed in national level.
\end{abstract}

Keywords: Culture, traditional sport, martial arts.

\section{PENDAHULUAN}

Undang-undang No. 3 tahun 2005 menyebutkan Industri olahraga adalah kegiatan bisnis bidang olahraga dalam bentuk produk barang dan/atau jasa. Industri olahraga akan mungkin terjadi apabila olahraga yang menjadi subjek bisnis mampu menarik partisipasi masyarakat yang cukup besar. Semakin besar jumlah partisipan dalam sebuah olahraga, maka potensi berkembangnya industri olahraga akan semakin besar pula.

\footnotetext{
Email : himasis_23@unpkediri.ac.id

No Handphone : 081227553480
} 
Pencak dor merupakan salah satu olahraga tradisional asal Kediri yang memiliki partisipan yang besar dari masyarakat. Partisipasi yang besar dari masyarakat ini memiliki potensi untuk mengembangkan industri olahraga. Penelitian ini akan mengukur seberapa besar potensi yang dimiliki oleh Pencak Dor untuk dikembangkan dalam industri olahraga.

Pengembangan daerah perlu memperhatikan potensi daerah dengan memperhatikan produk domestik regional bruto atau PDRB (Husna, Noor dan Rozikin (2012). Tujuan akhir dari pembangunan daerah adalah kesejahteraan masyarakat daerah. Potensi yang dimiliki oleh daerah dapat memiliki berbagai bentuk, salah satu contohnya di Kediri adalah Pencak Dor. Pencak Dor memiliki potensi untuk dikembangkan menjadi sebuah industri olahraga daerah. Setiap acara ini digelar, tidak kurang ada ribuan masyarakat yang datang dan menyaksikan pagelaran ini. Namun meskipun dalam pagelaran ini diikuti oleh ribuan masyarakat, pagelaran ini masih belum memberikan sumbangsih terhadap Pendapatan Asli Daerah (PAD). Dampak pegaruh PAD akan memberikan sumber bagi pemerintah dalam menciptakan segala kebutuhannya hal ini agar memberikan suatu kompetisi daerah-daerah untuk bersaing menjadi yang terbaik dalam era otonomi daerah yang berjalan saat ini (Rani, 2014).

Pencak Dor memiliki potensi ekonomi dan potensi wisata apabila dikembangkan dengan baik. Potensi ekonomi suatu daerah dapat dikembangkan melalui berbagai hal. Rusdarti (2010) menyatakan bahwa pengembangan potensi ekonomi daerah dapat dilaksanakan salah satunya menggunakan Usaha Kecil dan Menengah (UKM). Pencak Dor sendiri merupakan seni tradisi asli masyarakat Kediri. Seni tradisi yang hanya ada di masyarakat Kediri ini memiliki kempuan pengembangan UKM daerah Kediri. Sektor pariwisata merupakan industri yang digerakan oleh pasar. Untuk memasarkan produk wisata tersebut diperlukan adanya keterlibatan semua pihak yang terlibat dalam pengelolaan wisata mulai dari pengelola wisata, pemerintah, dan masyarakat. Namun, terkadang terdapat kemunduran dari wisata yang diunggulkan karena kurangnya kontrol dari pemerintah. Hidayat (2011) memberikan rekomendasi kerja 
sama antar pemerintah dengan pihak pengelola untuk mengembalikan dan memperbaiki keindahan dari objek wisata. Pencak Dor memiliki potensi wisata karena keindahan seni bertarung yang dipertunjukkan. Namun semakin kebelakang, keindahan seni dari Pencak Dor juga semakin hilang. Diperlukan dukungan pemerintah yang dibantu pihak pengelola untuk memperbaikinya.

Industri olahraga, terutama olahraga daerah tidak terlepas dari potensi yang dimiliki oleh daerah tempat olahraga tersebut lahir. Pencak Dor merupakan olahraga tradisional yang lahir dari daerah Kediri yang telah memiliki partisipan yang cukup besar. Hingga saat ini besarnya partisipan masih belum bisa dimanfaatkan menjadi sebuah industri olahraga yang baik. Telaah dari penelitian ini diharapkan dapat digunakan sebagai pertimbangan untuk mengembangkan potensi dari Pencak Dor dalam sektor industri olahraga.

\section{METODE}

Penelitian ini termasuk penelitian lapangan yang merupakan penelitian kualitatif dengan pendekatan fenomenologi. Fenomenologi adalah studi tentang pengalaman manusia dan cara-cara yang ada dalam diri kita dan melalui pengalaman seperti itu (Sokolowsky 2000 dalam Gallagher, 2012). Dalam pendekatan fenomenologi ini peneliti mempuyai tujuan menemukan, memahami, menjelaskan, dan memperoleh gambaran fenomena-fenomena pergeseran makna dari pertarungan Pencak Dor. Dengan demikian, pendekatan fenomenologi dalam penelitian ini digunakan untuk menggali data tentang pergeseran makna partisipasi diri dari petarung Pencak Dor.

Teknik yang digunakan untuk mengumpulkan data dalam penelitian ini adalah wawancara. Wawancara saat ini menjadi prosedur pengambilan data utama dalam penelitian yang terkait dengan penelitian kualitatif (Englander, 2012). Saat ini interview juga sering digunakan untuk memperoleh hasil pengetahuan yang luas di seluruh ilmu pengetahuan (Brinkmann, 2014). Metode wawancara dipilih untuk mengetahui 
pengalaman para partisipan dari Pencak Dor selama pertandingan. Wawancara yang digunakan menggunakan pola fikir yang terbentuk dari pengalaman responden, dan peneliti tidak akan memaksakan kehendak terkait jalanya penelitian ini. Subjek penelitian yang digunakan dalam penelitian ini terdiri dari petarung, mantan petarung, pengelola, dan ketua pengasuh paguyuban pencak dor. Subjek tersebut merupakan subjek yang serig terlibat langsung dalam kegiatan pagelaran pencak dor, baik sebelum, ketika, dan setelah kegiatan. Penggunaan subjek yang terlibat secara langsung memiliki tujuan agar data yang dihasilkan berdasarkan pengalaman dari para petarung. Teknik sampling yang digunakan dalam penelitian ini adalah purposive sampling. Purposive sampling merupakan teknik pengambilan sumber data dengan pertimbangan tertentu (Sugiyono, 2009). Pertimbangan yang digunakan dalam penelitian ini adalah subjek yang terlibat secara langsung dalam setiap kegiatan pencak dor.

\section{HASIL}

Pencak Dor lahir pada tahun 1942 dari ponpes Lirboyo di Kediri yang dicetuskan oleh $\mathrm{KH}$. Mahrus. Pada masa itu Indonesia masih dalam masa penjajahan Jepang. Dikisahkan pada masa awal munculnya, Pencak Dor dilarang oleh pihak Jepang. Namun KH. Mahrus menjelaskan kepada pihak Jepang bahwa Pencak Dor merupakan seni pertunjukan tari, sehingga pihak Jepang mengijinkan berlangsungnya Pencak Dor. Terdapat pendekar yang termasyhur hingga di luar kota Kediri, yaitu $\mathrm{KH}$. Maksum, atau lebih dikenal dengan nama Gus Maksum. Terdapat tiga periode dalam kepemimpinan pencak dor. Tiap periode memiliki ciri khas yang berbeda-beda.

Tabel 1 Ciri khas Pencak Dor tiap periode

\begin{tabular}{lccc}
\hline Periode & $\begin{array}{c}\text { Ketua } \\
\text { Umum }\end{array}$ & Tahun & \multicolumn{1}{c}{ Ciri khas } \\
\hline \multirow{3}{*}{ Petama } & Kh Mahrus & \multirow{2}{*}{$1942-1960$} & a. Merupakan pencak murni \\
\cline { 3 - 4 } & & b. $\begin{array}{l}\text { Mengedepankan seni } \\
\text { gerakan }\end{array}$ \\
\cline { 3 - 4 } & & C. Ajang silaturahmi pendekar \\
\hline
\end{tabular}




\begin{tabular}{|c|c|c|c|}
\hline & & & e. Tidak ada aturan \\
\hline \multirow{3}{*}{ Kedua } & \multirow{3}{*}{$\begin{array}{l}\text { Kh Maksum } \\
\text { Jauhari }\end{array}$} & \multirow{3}{*}{$1960-1985$} & $\begin{array}{l}\text { a. Mulai dikenal oleh } \\
\text { masyarakat }\end{array}$ \\
\hline & & & $\begin{array}{l}\text { b. Mulai meniggalkan seni, } \\
\text { lebih kearah silat untuk } \\
\text { menyerang dan } \\
\text { mengalahkan lawan }\end{array}$ \\
\hline & & & $\begin{array}{l}\text { c. Sebagai jembatan warga } \\
\text { yang sering terlibat tawuran } \\
\text { untuk menyalurkan hasrat } \\
\text { untuk bertarung dengan } \\
\text { benar }\end{array}$ \\
\hline \multirow{4}{*}{ Ketiga } & \multirow{4}{*}{$\begin{array}{l}\text { Kh Zainal } \\
\text { Abidin }\end{array}$} & \multirow{4}{*}{ 1985-sekarang } & $\begin{array}{l}\text { a. Pencak mulai diikuti } \\
\text { berbagai macam kalangan } \\
\text { masyarakat }\end{array}$ \\
\hline & & & $\begin{array}{l}\text { b. Diikuti berbagai macam bela } \\
\text { diri }\end{array}$ \\
\hline & & & $\begin{array}{l}\text { c. Memiliki kesan brutal dan } \\
\text { liar }\end{array}$ \\
\hline & & & d. Mulai menggunakan wasit \\
\hline
\end{tabular}

Jika dilihat dari periodisasi yang telah dijabarkan di atas, dapat diketahui bahwa partisipan setiap periode semakin meningkat. Jumlah partisipan yang semakin meningkat ini memunculkan potensi yang besar dari arah industri olahraga. Industri olahraga yang bisa dikembangkan dari Pencak Dor berasal dari sektor ekonomi dan sektor wisata. Sektor ekonomi dari Pencak Dor sendiri dapat dikembangkan dari atribut yang digunakan selama pertandingan.

Meskipun termasuk olahraga tradisional yang belum secara resmi diakui oleh pemerintah, namun Pencak Dor tetap memiliki atribut khusus yang digunakan selama pertandingan. Terdapat dua atribut khusus yang ada dalam olahraga Pencak Dor, yaitu genjot dan tabuhan jedor. Genjot merupakan sebuah panggung yang konstruksinya terdiri dari bambu yang disusun menyerupai ring tinju. Saat ini konstruksi genjot menjadi lebih modern dengan menggunakan struktur dasar dari besi. Sedangkan pembatas yang mengelilinginya masih terbuat dari bambu. Hal ini bertujuan untuk alasan keamanan dengan tetap menjaga tradisi yang digunakan sejak dulu. 


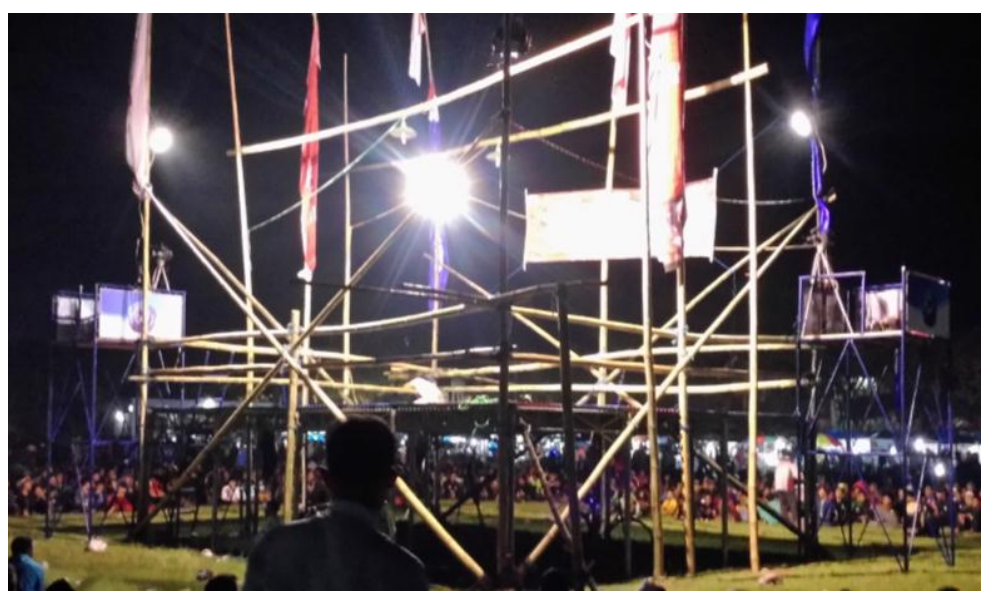

Gambar 1 Genjot yang Digunakan Selama Pertandingan

Meskipun tampak sederhana, dengan konstruksi yang lebih modern genjot yang digunakan mampu menahan beban yang cukup berat dari petarung di atasnya. Bahkan tidak jarang banyak petarung yang belum waktunya bertarung sudah ikut naik ke atas genjot. Selain genjot, digunakan pula tabuhan jedor yang mengiringi pada tiap pertandingan. Jedor merupakan istilah yang melatar belakangi munculnya istilah Pencak Dor. Sebenarnya jedor merupakan iringan dari musik hadrah yang melantunkan shalawat badar selama pertandingan. Ini merupakan tradisi yang telah ada sejak munculnya Pencak Dor. Iringan musik dari jedor berasal dari bermacam-macam alat musik, diantaranya adalah kendang, gong, dan bedug. Jedor berada di atas selasar khusus yang terpisah dari arena, namun tetap dekat dengan arena. Pada selasar tersebut juga terdapat pemandu acara yang selalu mengomentari jalannya pertandingan. 


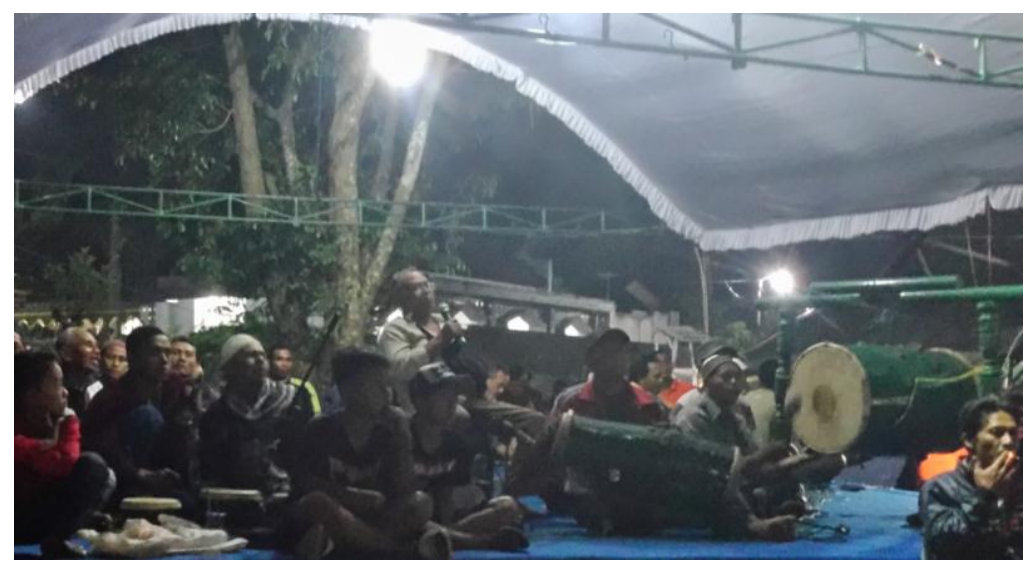

Gambar 2 Iringan Musik Jedor

Untuk atribut lain yang digunakan pada Pencak Dor masih bersifat kesepakatan, yang mana berbeda-beda tiap pertandingan. Terdapat pertandingan yang mengisyaratkan menggunakan songkok atau peci ketika bertanding. Ada pula yang mewajibkan menggunakan alat pengaman ketika pertandingan. Namun hal itu semua masih belum masuk dalam aturan tetap yang tertulis dan harus dipatuhi.

Jumlah penonton yang datang untuk menyaksikan pencak dor tiap tahun semakin bertambah. Penoton yang datang berasal dari berbagai golongan masyarakat. Ada yang datang khusus dengan rombongannya dengan menaiki truk bak terbuka bersama-sama. Umumnya golongan ini berasal dari sebuah perguruan silat tertentu yang sengaja datang untuk turut serta berpartisipasi dalam pertandingan. Selain dari sebuah perguruan tertentu, ada pula warga satu desa yang datang bersama-sama dengan menyewa truk agar bisa datang secara bersama-sama. Kadangkadang ada juga penonton yang datang dari luar kota. Mereka jauh datang dari luar kota untuk melihat jalannya Pencak Dor karena mereka merupakan pengamat atau penikmat budaya. 


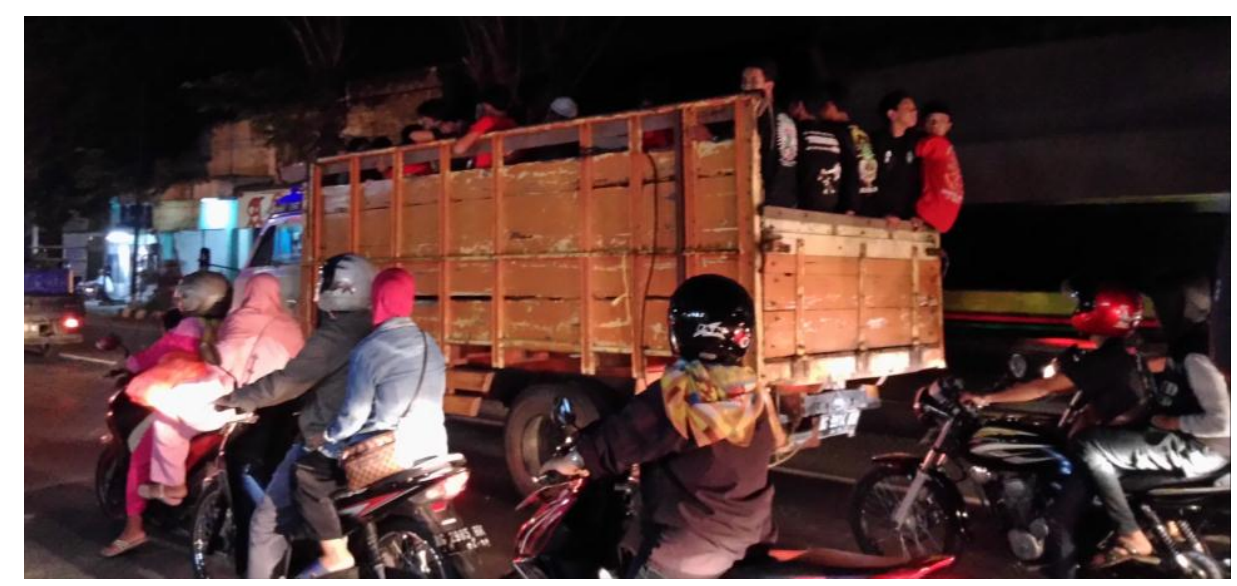

Gambar 3 Rombongan yang Datang dengan Menggunakan Truk Bak Terbuka

Banyaknya jumlah penonton terkadang membuat kondisi tidak kondusif. Semakin malam acara digelar, maka jumlah penonton yang datang semakin banyak pula. Semakin banyak penonton yang datang, terkadang kondisi semakin tidak kondusif. Tidak jarang terjadi keributan dari area penonton yang datang untuk menyaksikan Pencak Dor. Namun saat ini kondisi penonton yang menyaksikan pencak dor semakin kondusif dan tertata. Hal ini tidak terlepas dari usaha pengelola pelestari paguyuban Pencak Dor. Saat ini telah jarang terjadi tawuran antar penonton ketika acara telah dimulai.

Saat ini pelaksanaan pencak dor lebih tertata karena seluruh penonton yang datang tidak berdiri seperti menonton sebuah konser pertandingan. Penonton yang datang duduk dengan rapi mengelilingi genjot secara teratur. Kondisi ini mengisyaratkan bahwa saat ini penonton lebih menikmati pertandingan dengan baik, dan tidak ada keinginan untuk menimbulkan konflik saat pertandingan. Tampak semakin maju zaman, kedewasaan dari partisipan juga semakin terbentuk. Apabila hal ini dapat dilaksanakan secara berkelanjutan, bukan tidak mungkin pencak dor menjadi sebuah olahraga resmi yang dipertandingkan secara resmi dalam kejuaraan nasional. 


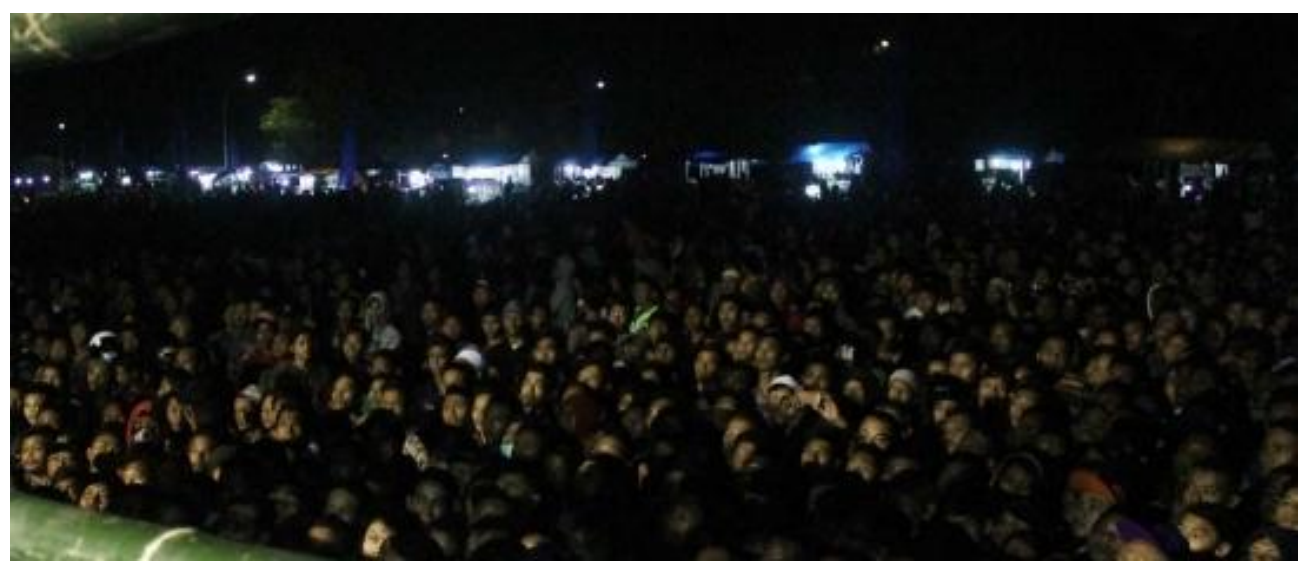

Gambar 4 Kondusifitas Penonton Selama Pertandingan

Saat ini memang Pencak Dor masih belum menjadi sebuah pertandingan yang secara resmi diakui oleh pemerintah. Pencak Dor masih berada di bawah naungan pihak pengelola paguyuban pelestari yang masih belum resmi. Namun saat ini sudah dilakukan berbagai upaya agar Pencak Dor menjadi sebuah olahraga yang diakui keberadaanya oleh pemerintah secara resmi. Apabila Pencak Dor telah resmi diakui oleh pemerintah, maka akan terdapat dampak yang besar terhadap seluruh partisipan dari Pencak Dor. Selain bagi partisipan, peremian Pencak Dor akan memberikan pengaruh terhadap kota Kediri. Karena secara tidak langsung Pencak Dor akan menambah PAD kota Kediri.

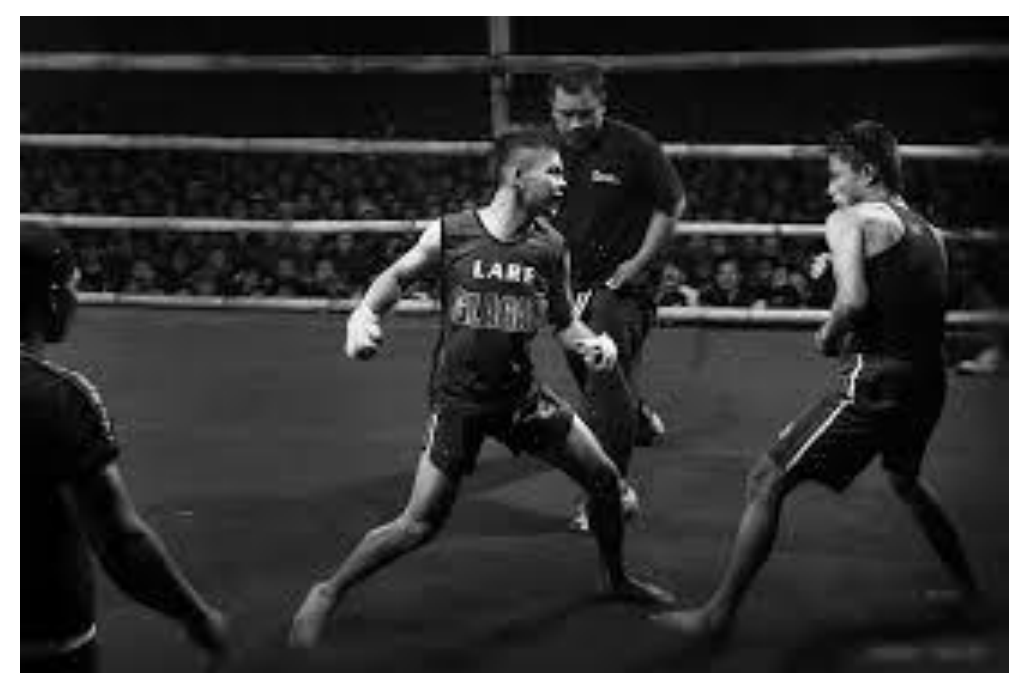

Gambar 5 Pertarungan di Atas Genjot Pencak Dor 
Wasis Himawanto

Pencak Dor dalam Industri Olahraga

\section{PEMBAHASAN}

Pencak Dor merupakan salah satu jenis olahraga tradisional yang lahir ditengah masyarakat. Lahir di tengah masyarakat membuat Pencak Dor dengan mudah diterima oleh masyarakat. Pencak dor merupakan adat istiadat yang lahir di tengah masyarakat. Adat istiadat yang lahir di tengah masyarakat begitu kuat, sehingga sulit dilepaskan oleh masyarakat (Nasir, 2014). Kuatnya ikatan antara masyarakat dengan adat budaya ini memberikan dampak banyaknya masyarakat yang datang untuk berpartisipasi dalam Pencak Dor. Ramainya pengunjung dan peserta Pencak Dor memunculkan potensi industri olahraga di sektor ekonomi dan pariwisata.

Sektor ekonomi yang muncul dengan adanya Pencak Dor dapat dimanfaatkan oleh berbagai kalangan masyarakat. Masyarakat yang kesehariannya merupakan penjual jajanan atau lebih dikenal dengan PKL banyak yang membuka lapak di sekitar pagelaran ini. PKL memilih lokasi yang banyak dikunjungi oleh khalayak ramai untuk membuka lapak (Susilo, 2011). Selain itu rendahnya harga sewa juga mempengaruhi pola pemilihan lokasi berjualan. Penggunaan lokasi baru dengan harga sewa yang tinggi memberatkan pedagang untuk berkembang (Kasrimadi, 2015). Sedangkan pada pagelaran Pencak Dor harga sewa yang ditarik tidak begitu tinggi, dan jumlah masyarakat yag datang begitu ramai. Ini tentu hal yang diinginkan oleh para PKL. Namun ada dampak negatif dari kebijakan ini, yaitu kurang bersihnya lokasi setelah selesai acara. Minimnya pengetahuan dan rendahnya sikap masyarakat terkait kebersihan lingkungan merupakan penyebab kurang bersihnya lokasi (Nazzarudin, 2014). Kebanyakan PKL tidak menyediakan tempat khusus untuk area makan dan pembuangan sampah makanan. Ini semakin memperparah sikap masyarakat yang kurang peduli lingkungan. Pengelolaan yang baik dari panitia diperlukan agar antara panitia dan PKL bisa bekerja sama dalam menjaga kebersihan. 


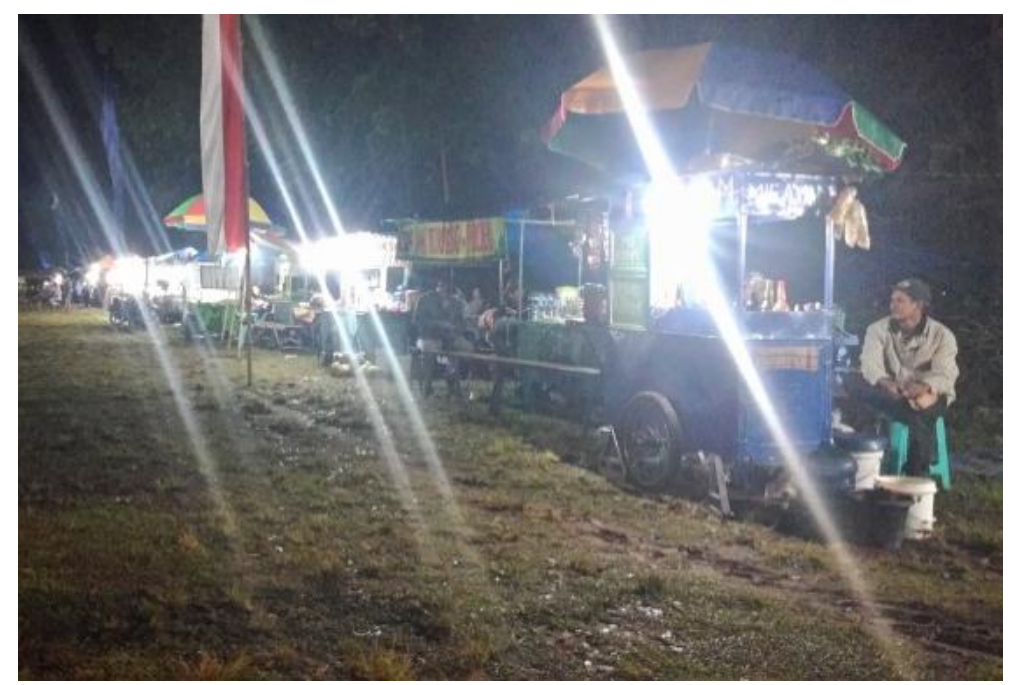

Gambar 6 Pedagang Kaki Lima yang Tertata Rapi Diluar Arena Pertandingan

Sebelum melangkah ke arah yang lebih jauh, diperlukan perbaikan infrastruktur dalam Pencak Dor. Infrastruktur sendiri merupakan prasyarat bagi sektor-sektor lain untuk berkembang dan juga sebagai sarana penciptaan hubungan antara satu dengan yang lainnya (Warsilan \& Noor, 2015). Semakin baik infrastrukur yang digunakan, maka perkembangan ekonomi yang mungkin terjadi akan semakin besar pula (Maryaningsih, Hermansyah, \& Safitri, 2014). Infrastruktur yang memerlukan perbaikan diantaranya adalah genjot yang digunakan dalam pertandingan. Diperlukan struktur yang lebih rapi dari genjot yang digunakan dengan menghilangkan beberapa tiang yang digunakan sebagai penyangga lampu. Penyangga lampu dapat menggunakan besi atau tiang yang diletakan secara terpisah dengan genjot. Konsep yang digunakan dapat meniru lampu pada pertandingan sepak bola dengan ukuran lampu yang lebih kecil.

Untuk membuat Pencak Dor semakin dikenal oleh masyarakat luas, diperlukan sebuah promosi kepada khalayak di luar Kediri. Iklan memberikan keuntungan bagi pihak retail (Lewis \& Reiley, 2014). Penggunaan iklan juga berpengaruh secara dominan terhadap niat beli dari konsumen (Prasetyo, 2013). Secara garis besar media periklanan digunakan untuk memberikan informasi mengenai sesuatu, umumnya produk-produk perusahaan kepada masyarakat umum. Pemanfaatan 
video dalam media periklanan dapat memberikan visualisasi yang lebih detail, ditambah dengan dukungan audio sehingga pesan dari iklannya dapat tersampaikan (Hermawan \& Ardiyansyah). Untuk mengenalkan Pencak Dor kepada khalayak ramai, selain menggunakan brosur dan banner juga dapat menggunakan media berupa video. Pola penyebarannya melalui media sosial seperti facebook, Instagram, dan youtube. Jenis video yang digunakan sebagai iklan dapat berupa film dokumenter. Thonon et al. (2016) melakukan penelitian tentang penggunaan film dokumenter terhadap penderita schizophrenia. Hasilnya adalah penggunaan film dokumenter memiliki dampak yang ekslusif terhadap penderita schizophrenia. Dari hal ini diketahui bahwa film dokumenter mampu mempengaruhi sikap seseorang terhadap sesuatu. Pengemasan yang baik dari film dokumenter ini akan menimbulkan ketertarikan dari masyarakat terhadap Pencak Dor.

Sektor pariwisata juga dapat dimanfaatkan dalam pengembangan Pencak Dor. Pencak Dor merupakan seni tradisi yang lahir sejak Indonesia belum memperoleh kemerdekaan. Keindahan gerakan asli dari pencak dor akan mengundang para wisatawan dari berbagai daerah untuk datang untuk menyaksikan Pencak Dor. Sektor wisata erat kaitanya dengan sektor ekonomi. Semakin baik sektor wisata dari sebuah daerah, maka sektor ekonomi daerah tersebut semakin baik pula. Nizar (2011) mengemukakan bahwa Pertumbuhan pendapatan pariwisata akan mendorong peningkatan pertumbuhan ekonomi dengan waktu triwulan. Artinya, peningkatan pendapatan pariwisata tahun sebelumnya baru akan terlihat pengaruhnya terhadap peningkatan pertumbuhan ekonomi pada triwulan pertama dan kedua tahun yang akan datang. Pertumbuhan ekonomi mendorong peningkatan pendapatan pariwisata dengan segera, yaitu pada triwulan berikutnya. Pengaruh ini berlangsung selama 3 triwulan. Artinya, pertumbuhan ekonomi tahun sebelumnya akan mendorong peningkatan pendapatan pariwisata selama 3 triwulan pertama tahun berjalan. Penelitian tersebut membuktikan bahwa sektor ekonomi dan sektor pariwisata saling memiliki keterkaitan. 
Sektor pariwisata juga memiliki pengaruh terhadap kualitas hidup masyarakat sekitar. Namun seperti yang dikemukakan oleh Nizar (2011), perubahan ini tidak serta merta dapat terjadi secara langsung. Namun bertahap selama beberapa bulan hingga tahun. Pencak Dor yang berkembang di daerah Kediri selama bertahun-tahun memberikan dampak terhadap masyarakat tentang kualitas hidup. Dari segi kesehatan, masyarakat yang sering turun dan terlibat dalam Pencak Dor memiliki kesehatan yang lebih baik. Selain dari segi kesehatan dari segi struktur bangunan rumah sekitar daerah yang sering dilaksanakan Pencak Dor juga terdapat perubahan. Rumah-rumah disekitar lapangan yang sering digunakan untuk pertandingan memiliki halaman yang luas. Hal ini menyikapi ketika dilaksanakan Pencak Dor, halaman rumah mereka bisa digunakan sebagai lahan parkir. Kim, Uysal, \& Sirgy (2013) meneliti tentang hal yang sama, yaitu hubungan sektor pariwisata terhadap kesejahteraan masyarakat sekitar. Digunakan empat dimensi untuk mengukur keterlibatan sektor pariwisata terhadap kesejahteraan masyarakat, yaitu ekonomi, sosial, budaya, dan lingkungan. Hasil penelitian oleh Kim et al. (2013) menyatakan bahwa sektor pariwisata memilki pengaruh terhadap keempat dimensi yang telah disebutkan. Pariwisata juga menimbulkan persepsi yang mempengaruhi kesejahteraan masyarakat sekitar.

Namun saat ini unsur seni dalam Pencak Dor mulai luntur. Asimilasi berbagai perguruan silat yang ikut serta membuat Pencak Dor perlahanlahan mulai kehilangan unsur seninya. Kini pencak dor lebih mengedepankan bela diri dan kontak fisik daripada unsur seninya. Rosana (2011) mengemukakan Modernisasi dan perubahan sosial merupakan dua hal yang saling berkaitan. Modernisasi pada hakikatnya mencakup bidang-bidang yang sangat banyak, bidang mana yang akan diutamakan oleh suatu masyarakat tergantung dari kebijakan penguasa yang memimpin masyarakat tersebut. Modernisasi hampir pasti pada awalnya akan mengalami disorganisasi dalam masyarakat, apalagi yang menyangkut nilai-nilai dan norma-norma dalam masyarakat, dimana 
masyarakat yang bersangkutan belum siap untuk berubah, karena perubahannya begitu cepat serta tidak mengenal istirahat. Hal tersebut akan mengakibatkan disorganisasi yang terus menerus, karena masyarakat tidak pernah sempat untuk mengadakan reorganisasi. Namun seiring berjalannya waktu, masyarakat akan mulai menyesuaikan diri dengan keadaan tersebut.

Tidak dapat dipungkiri, Pencak Dor juga mengalami modernisasi. Berbagai perubahan terjadi dalam beberapa aspek yang ada dalam Pencak Dor. Apabila tidak ada kontrol terhadap modernisasi, maka unsur budaya yang dalam Pencak Dor akan mulai luntur dan menghilang. Azali (2012) yang meneliti tentang ludruk mengatakan bahwa perlu dilakukan sinergi dan kolaborasi yang aktif, berorientasi panjang, dan berkelanjutan antara pelaku, penikmat (publik), peminat bisnis, serta pemerintah, agar dapat melestarikan dan mengembangkan kesenian ini sesuai dengan perkembangan zaman global dengan media tontonan dan hiburan yang makin bersaing. Semua itu dilakukan agar ludruk tidak punah diterjang modernisasi. Hal yang sama perlu pula dilakukan terhadap Pencak Dor. Diperlukan penggiat dan pelestari agar keberadaan seni budaya dalam Pencak Dor tetap lestari dengan baik.

\section{KESIMPULAN}

Berdasarkan paparan di atas dapat disimpulkan sebagai berikut:

1. Pencak Dor memiliki potensi untuk berkembang dalam industri olahraga. Hal ini karena masyarakat yang datang sebagai partisipan memiliki jumlah yang besar.

2. Upaya untuk mengembangan industri olahraga di Pencak Dor masih terkendala oleh kelembagaan yang belum dibentuk. Infrastruktur yang kurang sesuai juga memiliki pengaruh terhadap pengembangan industri olahraga ini.

3. Untuk lebih memperbesar jangkauan dalam pemasaran Pencak Dor, dapat digunakan media berupa video. Penyebaran iklan dapat menggunakan media sosial berupa facebook dan youtube. 
4. Masyarakat sekitar menjadi pelaku utama dalam mengembangkan potensi ekonomi dari industri olahraga ini. Masyarakat harus bersinergi dengan pihak pengelola untuk mengembangkan potensi ekonomi dari Pencak Dor.

5. Diperlukan kontrol dari modernisasi dalam Pencak Dor untuk mencegah lunturnya budaya asli dalam Pencak Dor. Kontrol modernisasi dapat dilakukan oleh penggiat, pengelola, dan masyarakat yang aktif dalam Pencak Dor.

\section{DAFTAR PUSTAKA}

Brinkmann, S. 2014. Interview. In Encyclopedia of Critical Psychology (pp. 1008-1010). Springer New York.

Englander, M. 2012. The Interview: Data Collection in Descriptive Phenomenological Human Scientific Research. Journal of Phenomenological Psychology. 43(1); 13-35.

Gallagher, S. 2012. What Is Phenomenology?. InPhenomenology (pp. 718). Palgrave Macmillan UK.

Hermawan, D \& Ardiyansyah, F.(tanpa tahun). Pembuatan Iklan Berbasis Video pada Perusahaan R2SHOP Bandung. Jurnal PKN LPKIA.

Husna, N., Noor, I., dan Rozikin, M. 2012. Analisis Pengembangan Potensi Lokal untuk Menguatkan Daya Saing Daerah di Kabupaten Gresik. Jurnal Administrasi Publik. 1(1); 188-196.

Kasrimadi. 2015. Penataan dan Pemberdayaan Pedagang Kaki Lima (Pkl) diKecamatan Tualang Perawang Kabupaten Siak Tahun 2013. Jom FISIP. 2(1); 1-14.

Kim, K., Uysal, M., \& Sirgy, M. J.2013. How does tourism in a community impact the quality of life of community residents?. Tourism Management. 36(52); 527-540.

Lewis, R. A.,\& Reiley, D. H. 2014. Online ads and offline sales: measuring the effect of retail advertising via a controlled experiment on Yahoo!. Quantitative Marketing and Economics, 12(3); 235-266.

Maryaningsih, Hermansyah, \&Safitri. 2014. Pengaruh Infrastruktur terhadap Pertumbuhan Ekonomi di Indonesia. Buletin Ekonomi Moneter dan Perbankan. 17(1); 61-98.

Nasir, S. R. R. 2014. Perubahan Sosial Masyarakat Lokal Akibat Perkembangan Pariwisata Dusun Wakka Kab. Pinrang (Interaksi 
Antara Wisatawan \& Masyarakat Lokal). Skripsi. Makassar: Universitas Hassanudin.

Nizar, M. 2011. Pengaruh Pariwisata Terhadap Pertumbuhan Ekonomi di Indonesia. University Library of Munich, Germany.

Rani, D. P. M. 2014. Pengembangan Potensi Pariwisata Kabupaten Sumenep, Madura, Jawa Timur (Studi Kasus: Pantai Lombang). Jurnal Politik Muda. 3 (3); 412-421.

Rosana, E. 2011. Modernisasi dan Perubahan Sosial. Jurnal TAPIs. 7(12); 30-47.

Rusdarti. 2010. Potensi Ekonomi Daerah dalam Mengembangkan UKM Unggul di Kabupaten Semarang. JEJAK. 3(2); 143-155.

Prasetyo, E. S. 2013. Pengaruh Iklan, Promosi Penjualan dan PenjualanPerorangan Terhadap Niat Beli di CV. Lancar Makmur Motor Surakarta. Agora. 1(3).

Sugiyono. 2009. Metode Penelitian Pendidikan Pendekatan Kuantitatif, Kualitatif, dan R\&D. Bandung: Alfabeta.

Susilo, Agus. 2011. Perubahan Sosial Masyarakat Lokal AkibatPerkembangan Pariwisata Dusun WakkaKab. Pinrang (Interaksi Antara Wisatawan dan Masyarakat Lokal). Tesis. Jakarta: Universitas Indonesia

Thonon, B., Pletinx, A., Grandjean, A., Billieux, J., \& Larøi, F. 2016. The effects of a documentary film about schizophrenia on cognitive, affective and behavioural aspects of stigmatisation. Journal of behavior therapy and experimental psychiatry, 50, 196-200.

Warsilan \& Noor, A. 2015. Peranan Infrastruktur terhadap Pertumbuhan Ekonomi danlmplikasi pada Kebijakan Pembangunan di Kota Samarinda. Mimbar. 31(2); 359-366. 